El bienestar de los docentes en tiempos de pandemia Covid-19: factores que explican el bienestar profesional

\title{
Teachers' well-being in times of Covid-19 pandemic: factors that explain professional well-being
}

Regina Alves.

CIEC - Research Center of Child Studies. Institute of Education, University of Minho (Portugal). rgnalves@gmail.com

Teresa Lopes.

CIEC - Research Center of Child Studies. Institute of Education, University of Minho (Portugal). teresaflopes@netcabo.pt

José Precioso.

CIEC - Research Center of Child Studies. Institute of Education, University of Minho (Portugal).

precioso@ie.uminho.pt

\section{RESUMEN.}

El objetivo de este estudio transversal fue describir y analizar factores relacionados con el bienestar profesional de los docentes portugueses durante la pandemia de COVID-19. Se aplicó un cuestionario validado, anónimo y en línea a una muestra no probabilística de docentes portugueses. Además de las variables sociodemográficas y profesionales, el cuestionario midió el bienestar subjetivo y profesional, la satisfacción con el sistema educativo y las perspectivas futuras con respecto a las circunstancias profesionales. Se analizaron las características psicométricas del cuestionario, se utilizó la prueba t y ANOVA para analizar las diferencias entre las principales variables y las características sociodemográficas y profesionales, junto con el modelo lineal generalizado para determinar con mayor precisión los factores predictores de Bienestar profesional de los docentes. Los resultados mostraron que la mayoría de los encuestados tienen una percepción moderadamente positiva del bienestar. Los docentes estaban satisfechos con el sistema educativo antes de la pandemia. La pandemia ha reducido la percepción de bienestar frente a la profesión, creando cierta preocupación entre los docentes sobre su futuro profesional. El sexo, la duración del servicio, el bienestar, las percepciones de las dificultades de enseñanza y las perspectivas futuras demostraron ser predictores del bienestar profesional en tiempos de pandemia. Este estudio proporcionó bases científicas para el desarrollo de intervenciones que mejoran el bienestar profesional de los docentes, que se centran en el manejo emocional y el desarrollo de habilidades digitales en docentes con largas carreras. Esta investigación concluyó con evidencia exhaustiva de que existe la necesidad de una mayor y más fuerte inversión en políticas públicas para la reforma y, en consecuencia, para la renovación de la clase docente.

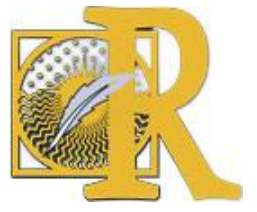

Fecha de recepción: 13-07-2020 Fecha de aceptación: 25-07-2020 
COVID-19, docentes, bienestar, satisfacción laboral, perspectivas de futuro.

\begin{abstract}
.
This cross-sectional study was aimed to describe and analyse factors related to the professional well-being of Portuguese teachers during the COVID-19 pandemic. A previously validated, anonymous and online questionnaire was applied to a non-probabilistic sample of Portuguese teachers. In addition to the socio-demographic and professional variables, the questionnaire measured subjective and professional well-being, satisfaction with the education system and future perspectives regarding the professional circumstances. The psychometric characteristics of the questionnaire were analysed, the t-test and ANOVA were used to analyse the differences between the main variables and the socio-demographic and professional characteristics, along with the generalized linear model in order to more precisely determine the predicting factors of teachers' professional well-being. The results showed that the majority of respondents have a moderately positive perception of well-being. Teachers were satisfied with the education system before the pandemic. The pandemic has reduced the perception of well-being in the face of the profession, creating some concern among teachers about their professional future. Sex, length of service, well-being, perceptions of teaching difficulties and future perspectives proved to be predictors of professional well-being in times of pandemic. This study provided scientific bases for the development of interventions that improve the professional well-being of teachers, which focus on emotional management and the development of digital skills in teachers with long careers. This piece of research concluded with thorough evidence that there is a need for further and stronger investment in public policies for the reform and, consequently, for the renewal of the teaching class.
\end{abstract}

\title{
KEY WORDS.
}

COVID-19, Teachers, Well-being, Job satisfaction, future perspectives.

\section{Introduction.}

The teaching profession appears in the scientific literature has having a history full of periods of crisis and discontent, strongly guided by high rates of professional dissatisfaction, stress, burnout and depression (Jensen et al., 2012; Kyriacou, 2001; Skaalvik \& Skaalvik, 2015), linked to the vast bureaucracy, the excessive workload, the growing number of students per class, the latters' lack of motivation and/or interest, incidents of indiscipline, precariousness and professional instability, the workload outside the school environment and the growing use of technology in teaching (Garrick et al., 2018; Jensen et al., 2012; Mattern \& Bauer, 2014; Skaalvik \& Skaalvik, 2015)..

Job satisfaction is composed of psychological, physiological and environmental conditions and factors that, together, guarantee positive feelings towards work (Aziri, 2011) and therefore increase the rate of productivity and sense of well-being. The literature review carried out by Hongying (2007) presents five explanatory factors for satisfaction with teaching work (school principals, teaching, professional colleagues, salaries and progression prospects), which cover aspects such as the nature of work, the intensity of said work, physical conditions, the

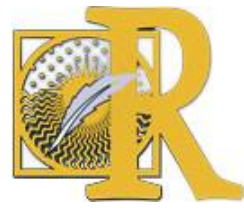

Fecha de recepción: 13-07-2020 Fecha de aceptación: 25-07-2020

Alves, R., Lopes, T \& Precioso, J. (2021). El bienestar de los docentes en tiempos de pandemia Covid-19: 
educational system and social environment, social status, wages, interpersonal relationships, school administration, student quality, career opportunities and professional development and self-realization.

Job satisfaction should be seen in the context of other key factors, such as general well-being, quality of life or stress at work. For this reason, professional well-being is also influenced by direct and continuous relationships with students (lack of discipline, low motivation to learn), with organizational factors (lack of recognition from colleagues, directors, time pressures, scarcity or even absence of resources) and with personal factors (low self-esteem) (Puertas Molero et al., 2019); all of these contributing aspects are of equal high relevance important at both the organizational level and the individual level (Briones et al., 2010; Mclnerney et al., 2018).

In the scientific literature, there are several definitions of job satisfaction that essentially encompass a positive emotional state (Inandi et al., 2013), a positive impact of work experiences (Gursel et al., 2002) or a positive perception towards work (Yorulmaz et al., 2017). In this article and in the specific case of teachers, we understand that job satisfaction refers to the way teachers feel about different aspects of their work (Spector, 1997), affecting their physical and psychological well-being (Briones et al., 2010). According to Demirel (2014)(Demirel, 2014), there is a significant relationship between the professional satisfaction of teachers and their level of satisfaction with life in more general terms. Likewise, a metaanalysis study also noted the existence of a negative correlation between emotional exhaustion and job satisfaction (Yorulmaz et al., 2017). Thus, it is observed that studies on the psychological health status of teachers are mainly associated with contexts of denial, such as stress and exhaustion (Spilt et al., 2011).

Constant changes in social structures and political systems also affect the well-being of teachers. However, recently, due to the COVID-19 pandemic, teachers worldwide have been faced with numerous and continuous changes in teaching structures (Reimer \& Schleicher, 2020), an aspect which we also consider to have a negative impact on the teachers' wellbeing, both personally and professionally. It was in this regard that the study emerged, aimed at analyzing the factors that contribute to the professional well-being of teachers in times of pandemic, controlling their satisfaction in the pre-pandemic period and their perspectives and prospects for their professional future.

\section{Methods.}

\subsection{Participants and procedure.}

This cross-sectional descriptive study was carried out between May 27 and June 6, 2020, using a non-probabilistic sample of Portuguese teachers, working in the academic year 2019/2020, using an online questionnaire. The questionnaire was formatted on Google forms preceded by the informed consent form; a link to provide access to the questionnaire was also sent by email, along with all information about the study, to all school directors in the country (including the autonomous regions, Azores and Madeira). In accordance with the internal regulations of each educational establishment, the link was disclosed to teachers, guaranteeing confidentiality, anonymity and voluntary participation. All ethical procedures for

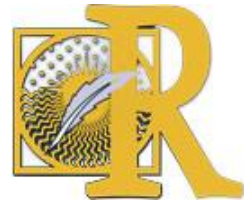

Fecha de recepción: 13-07-2020 Fecha de aceptación: 25-07-2020

Alves, R., Lopes, T \& Precioso, J. (2021). El bienestar de los docentes en tiempos de pandemia Covid-19: 
scientific investigations with human beings mentioned by Christensen, Johnson and Turner (2015) were followed.

\subsection{Instruments.}

Based on (inter)national scientific investigations and considering that teachers' well-being must be analysed in a positive perspective (Collie et al., 2015), several items commonly used to analyse job satisfaction and professional well-being were put into practice. Due to the emerging pandemic situation, it was no longer possible at the time of the construction of the research instruments to rely on scientific studies that addressed the satisfaction and wellbeing of teachers in similar situations.

Given the wide variety of topics generally considered to be related to well-being, we focus, as advised by Diener, Lucas and Oishi (20v18), on external influences on feelings of well-being. All this despite the fact that we are aware that financial stability or the quality of family life could be important determinant factors as well.

Before proceeding with data collection, the items grouped by the different scales that make up the questionnaire were subject to content validity by two researchers.

In addition to the socio-demographic and professional variables (gender, age, district where one teaches, recruitment group to which one belongs, level of education one teaches, length of service, current professional situation), the questionnaire comprises 31 additional questions, divided into 4 scales:

- Well-being and Health Perception Scale (WbHPS) (Alves et al., 2020): it is a brief wellbeing scale validated for university students and consists of 5 items (satisfaction with life, self-satisfaction, happiness felt, perceived health and satisfaction with physical form) evaluated using a 5-point Likert scale. In the present study, it showed a good reliability index $(\alpha=.828)$ and a factor that explains $60.78 \%$ of the variance, $\mathrm{KMO}=.806$ and with a component weight between .645 and .844 (Table 1).

- Satisfaction Scale with the Education System (SSES): this scale consists of 7 items and assesses the degree of satisfaction with the education system in the period prior to the pandemic taking into consideration the following aspects: Ministry of Education guidelines; School management support; Collaborative work with other teachers; established times; number of levels taught; bureaucracy; level of student commitment. The responses included a 5-point Likert scale (from 1 - Very dissatisfied to 5 - Very satisfied). This scale showed an acceptable reliability index $(\alpha=.771)$, reduced to a factor that explains $42.47 \%$ of the total variance of the data, $\mathrm{KMO}=.805$ and a weight of components between .554 and .736 (Table 1).

- Perception Scale of Well-Being with the Professional Situation in Times of Pandemic (PSWbPSTP): it is a scale composed of 12 items in order to compare the way they currently feel in relation to their professional situation, in comparison with what they felt before the pandemic. The perception of well-being was assessed by presenting 12 feelings or situations and assessed using a Likert scale (from 1 - Strongly Disagree to 5 Strongly Agree). The scale's validity was tested through reliability analysis and exploratory factor analysis, from which three factors were extracted, explaining $67.27 \%$ of the total variability, $\mathrm{KMO}=.860$.. The Positive perceptions factor is composed of 3 items (more

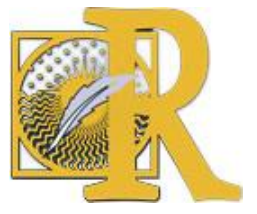

Fecha de recepción: 13-07-2020 Fecha de aceptación: 25-07-2020

Alves, R., Lopes, T \& Precioso, J. (2021). El bienestar de los docentes en tiempos de pandemia Covid-19: 
satisfied, more motivated, more valued) and has an acceptable reliability index $(\alpha=.694)$. The Negative perceptions factor includes 6 items (more tired, more stressed, more work overloaded, more anxious, more pressured and more anguished) and an excellent reliability index $(\alpha=.904)$. And the Teaching Difficulties perceptions factor composed of 3 items (difficulties with Distance Learning, difficulties with the use of digital platforms, difficulties with evaluation) and good reliability $(\alpha=.755)$ (Table 1).

- Professional Future Perspective Scale (PFPS): 8 items were used to assess how teachers perceive their professional situation, measured using a 5-point Likert scale (1 - Strongly Disagree and 5 - Strongly Agree). According to the exploratory factor analysis, these items are divided into two factors $(77.58 \%$ of the total variability, $\mathrm{KMO}=.766)$, according to the positive or negative tone of the perceived effects. Thus, positive perceptions regarding the future perspective refer to achievement, happiness, working conditions and prestige. And, in turn, in relation to negative perceptions, the items are related to the increase in work and bureaucracy $(\alpha=.813)$. It should be noted that two items that explained less than $40 \%$ of the data associated with the factor were eliminated from this factor and, in addition, decreased the scale's reliability index.

Table 1 - Items about each scale and factorial weight

\begin{tabular}{|c|c|c|c|c|}
\hline \multirow{2}{*}{$\begin{array}{l}\text { Scale items } \\
\text { WbHPS }\end{array}$} & \multirow[t]{2}{*}{$M(\mathrm{SD})$} & \multicolumn{3}{|c|}{ Factorial weight } \\
\hline & & & & \\
\hline Satisfaction with life & $3.61(.97)$ & & .844 & \\
\hline Self-satisfaction & $3.78(.90)$ & & .832 & \\
\hline Felt happiness & $3.61(.77)$ & & .837 & \\
\hline Perceived health & $3.64(.77)$ & & .719 & \\
\hline Satisfaction with physical form & $3.30(1.03)$ & & .645 & \\
\hline \multicolumn{5}{|l|}{ SSES } \\
\hline Ministry of Education guidelines & $3.00(.94)$ & & .630 & \\
\hline School management support & $3.96(.89)$ & & .696 & \\
\hline Collaborative work with other teachers & $3.98(.86)$ & & .625 & \\
\hline Established times & $3.79(.93)$ & & .736 & \\
\hline Number of levels taught & $3.81(1.05)$ & & .631 & \\
\hline Bureaucracy & $2.29(1.05)$ & & .674 & \\
\hline Level of student commitment & $3.57(.94)$ & & .554 & \\
\hline & & Positive & Negative & Teaching \\
\hline EBSPTP & & Perceptions & Perceptions & $\begin{array}{l}\text { Difficulties } \\
\text { Perceptions }\end{array}$ \\
\hline More satisfied & $2.24(.99)$ & .746 & & \\
\hline More tired & $4.15(.98)$ & & .813 & \\
\hline More motivated & $2.42(.93)$ & .820 & & \\
\hline More stressed & $3.88(1.09)$ & & .836 & \\
\hline More work overloaded & $4.26(.90)$ & & .813 & \\
\hline More anxious & $3.82(1.08)$ & & .818 & \\
\hline Most valued & $2.56(.969$ & .704 & & \\
\hline
\end{tabular}

Fecha de recepción: 13-07-2020 Fecha de aceptación: 25-07-2020 
Regina Alves, Teresa Lopes \& José Precioso. El bienestar de los docentes en tiempos de pandemia Covid-19: factores que explican el bienestar profesional

More pressed
More anguished
With difficulties with Distance Learning
With difficulties with the use of digital platforms
With difficulties with the evaluation

With difficulties with the evaluation
$3.57(1.03)$
$3.58(1.10)$
2.99(1.11)
$2.59(1.12)$
$3.42(1.13)$

.732

.746

.833

.871

.669

\begin{tabular}{|c|c|c|c|}
\hline PFPS & & $\begin{array}{l}\text { Positive } \\
\text { Perceptions }\end{array}$ & $\begin{array}{l}\text { Negative } \\
\text { Perceptions }\end{array}$ \\
\hline Will be more accomplished & $2.59(.92)$ & .904 & \\
\hline Will be happier & $2.61(.89)$ & .897 & \\
\hline Conditions will be better & $2.45(.93)$ & .839 & \\
\hline Your profession will have more prestige & $2.44(.97)$ & .695 & \\
\hline Your work will increase & $3.83(.83)$ & & .891 \\
\hline Bureaucracies will be increasingly & $3.93(.89)$ & & .900 \\
\hline
\end{tabular}

\subsection{Statistical analyse.}

The analysis was performed using IBM Statistical Package for the Social Sciences (SPSS) Statistics for Windows, version 26.0, Armonk, NY, USA. In order to analyse the psychometric characteristics of the scales, an exploratory factor analysis was carried out, using main component analysis with varimax rotation. An item was disregarded if the factor loading was less than 0.4. Afterwards, reliability was analysed through the calculation of item-total correlation coefficients and Cronbach's alpha $(\alpha)$ for the scales of the questionnaire. The descriptive analyses are presented in absolute $(n)$ and relative frequencies $(\%)$, mean $(M)$ and standard deviations $(S D)$. The scores for each subject in each of the scale factors were obtained by averaging the variables that constitute the factors. To analyse the differences between the main variables and the socio-demographic characteristics, the t-test and the oneway analysis of variance (ANOVA) were used, according to the variables, and the correlations between the main variables were calculated using Pearson's correlation. Finally, the generalized linear model was used to determine the predictors of teachers' professional wellbeing, which included all independent variables, except for age, as it has a high correlation with the variable length of service $(r=.835, \mathrm{p}<.001)$. The quality of the fit of the estimated models was adequate, with $X^{2} \operatorname{LR}(22)=535.75, p<.001$ and $X^{2} \operatorname{LR}(22)=584.974, p<.001$ (PSWbPSTP - Positive Perceptions and PSWbPSTP - Negative Perceptions, respectively). Statistical significance was defined as $p<.05$.

\section{Results}

The sample of this study consists of 1479 teachers (1162 females, 78.6\%). The most representative geographical area was the North of Portugal $(n=402,27.2 \%)$, followed by the Centre region ( $n=362,24.5 \%)$, and finally the Lisbon and Tejo area $(n=338,22.9 \%)$. The average age of the respondents was 51.34 years $(S D=7.27$, ranging from 26 to 68 years). The most prevalent length of service was the interval between 21 and 30 years $(n=607$, $41.0 \%)$, followed by service between 31 and 40 years $(n=430,29.1 \%)$. When questionnaires were applied, most teachers only taught distance learning $(n=1227,83.0 \%)$ and the majority

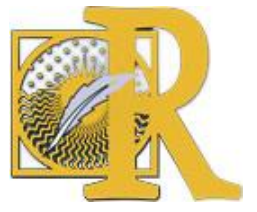


belonged to a recruitment group in the $3^{\text {rd }}$ cycle of Basic Education and Secondary Education $(n=880,61.2 \%)$ (Table 2).

The average WbHPS score was $3.59(S D=0.69)$, indicating that the teachers surveyed have moderate levels of well-being. In view of this variable, there were differences depending on the region where the teachers were teaching $(Z(6,1469)=2.845, p<.05)$ and the level of education they taught $(Z(4,1433)=2,799, p<.05)$. Thus, teachers who teach in the Azores region and in pre-school education showed better levels of well-being compared to teachers in the remaining regions of Portugal and the $1^{\text {st }}$ cycle of Basic Education (Table 2).

Before the pandemic, the teachers' level of satisfaction with the education system was moderate satisfied $(M=3.48, S D=0.62)$, with statistically significant differences depending on the region $(Z(4,1469)=4.229, p<.001)$, the length of service of teachers $(Z(4,1474)=$ $6,590, p<.001)$, the professional situation $(Z(2,1476)=4,625, p<.05)$ and the level of education $(Z(4,1433)=11.374, p<.001)$. This indicates that: teachers in the autonomous region of Madeira were more satisfied before the pandemic compared to teachers in the Algarve; teachers with fewer years of service (less than 10 years) were more satisfied than teachers with more years of service ( 21 and 30 years and 31 and 40 years); that teachers who taught only in person showed a higher level of satisfaction; and pre-school teachers were more satisfied compared to teachers in the $3^{\text {rd }}$ cycle of Basic Education and Secondary Education (Table 2).

Table 2. Differences in outcomes according to the sociodemographic characteristics of the participants $(N=1479)$.

\begin{tabular}{|c|c|c|c|c|c|c|c|c|}
\hline \multirow[b]{3}{*}{$\begin{array}{l}\text { Sociodemographic } \\
\text { characteristics }\end{array}$} & \multirow[b]{3}{*}{$n(\%)$} & \multirow[b]{2}{*}{ WbHPS } & \multirow[b]{2}{*}{ SSES } & \multicolumn{3}{|c|}{ PSWbPSTP } & \multicolumn{2}{|c|}{ PFPS } \\
\hline & & & & $\begin{array}{l}\text { Positive } \\
\text { Perceptions }\end{array}$ & $\begin{array}{l}\text { Negative } \\
\text { Perceptions }\end{array}$ & $\begin{array}{l}\text { Teaching Difficulties } \\
\text { Perceptions }\end{array}$ & $\begin{array}{l}\text { Positive } \\
\text { Perceptions }\end{array}$ & $\begin{array}{l}\text { Negative } \\
\text { Perceptions }\end{array}$ \\
\hline & & $M(S D)$ & $M(S D)$ & $M(S D)$ & $M(S D)$ & $M(S D)$ & $M(S D)$ & $M(S D)$ \\
\hline \multicolumn{9}{|l|}{ Sex } \\
\hline Male & $317(21.4)$ & $3.65(.68)$ & $3.44(.63)$ & $2.38(.75)$ & $3.78(.86)^{*}$ & $2.77(.93)^{\star \star \star \star ~}$ & $2.51(.82)$ & $3.90(.77)$ \\
\hline Female & $1162(78.6)$ & $3.57(.69)$ & $3.50(.62)$ & $2.41(.75)$ & $3.90(.84)$ & $3.06(.90)$ & $2.53(.78)$ & $3.87(.79)$ \\
\hline \multicolumn{9}{|l|}{ Region } \\
\hline North & $402(27.2)$ & $3.61(.67)^{* *}$ & $3.53(.63)^{* * * *}$ & $2.43(.75)$ & $3.87(.86)^{\star \star *}$ & $2.95(.96)$ & $2.53(.78)$ & $3.87(.77)^{\star \star * *}$ \\
\hline Center & $362(24.5)$ & $3.54(.67)$ & $3.49(.62)$ & $2.38(.72)$ & $3.98(.78)$ & $3.03(.90)$ & $2.53(.79)$ & 3.89(.81) \\
\hline Lisbon and Tejo & $338(22.9)$ & $3.53(.71)$ & $3.43(.60)$ & $2.39(.79)$ & $3.84(.87)$ & $3.00(.91)$ & $2.49(.79)$ & $3.93(.77)$ \\
\hline Alentejo & $57(3.9)$ & $3.73(.66)$ & $3.47(.57)$ & $2.44(.65)$ & $3.73(.69)$ & $2.83(.90)$ & $2.44(.71)$ & $3.96(.72)$ \\
\hline Algarve & $92(6.2)$ & $3.52(.71)$ & $3.29(.63)$ & $2.22(.77)$ & $4.12(.83)$ & $3.05(.89)$ & $2.37(.81)$ & $4.11(.76)$ \\
\hline Madeira & $99(6.7)$ & $3.68(.68)$ & $3.69(.61)$ & $2.53(.76)$ & $3.57(.93)$ & $2.97(.91)$ & $2.61(.82)$ & $3.77(.78)$ \\
\hline Azores & $126(8.5)$ & $3.75(.68)$ & $3.50(.60)$ & $2.48(.76)$ & $3.83(.87)$ & $3.12(.86)$ & $2.69(.80)$ & $3.61(.85)$ \\
\hline \multicolumn{9}{|l|}{ Level of educación } \\
\hline Pre-school Education & $54(3.8)$ & $3.78(.65)^{*}$ & $3.74(.60)^{* * *}$ & $2.64(.77)^{\star}$ & $3.58(.86)^{\star \star}$ & $3.17(1.02)^{\star \star \star}$ & $2.70(.84)$ & $3.59(.81)^{\star \star}$ \\
\hline 1st cycle of Basic Education & $220(15.3)$ & $3.48(.75)$ & $3.58(.58)$ & $2.29(.75)$ & 4.03(.85) & $3.23(.88)$ & $2.54(.82)$ & $3.97(.76)$ \\
\hline 2nd cycle of Basic & $216(15.0)$ & $3.57(.70)$ & $3.62(.56)$ & $2.42(.74)$ & $3.97(.79)$ & $3.02(.92)$ & $2.58(.83)$ & $3.75(.82)$ \\
\hline Education & & & & & & & & \\
\hline $\begin{array}{l}\text { 3rd cycle of Basic Education } \\
\text { and Secondary Education }\end{array}$ & $880(61.2)$ & $3.61(.68)$ & $3.40(.64)$ & $2.41(.76)$ & $3.83(.86)$ & $2.92(.92)$ & $2.49(.78)$ & $3.92(.78)$ \\
\hline Special Education & $68(4.7)$ & $3.56(.58)$ & $3.63(.56)$ & $2.43(.739$ & $3.92(.81)$ & $3.05(.84)$ & $2.60(.76)$ & $3.85(.71)$ \\
\hline \multicolumn{9}{|l|}{ Length of service } \\
\hline Less than 10 years & $66(4.5)$ & $3.62(.80)$ & $3.67(.61)^{* * * 8}$ & $2.43(.73)$ & $3.92(.83)$ & $2.83(.95)^{\star \star \star}$ & $2.99(.84)^{* * *}$ & $3.77(.79)$ \\
\hline Between 11 and 20 years & $292(19.7)$ & $3.57(.73)$ & $3.62(.61)$ & $2.38(.75)$ & $3.87(.85)$ & $2.83(.90)$ & $2.61(.77)$ & $3.83(.80)$ \\
\hline Between 21 and 30 years & $607(41.0)$ & $3.57(.70)$ & $3.45(.64)$ & $2.38(.76)$ & $3.89(.85)$ & $2.92(.90)$ & $2.46(.77)$ & $3.93(.80)$ \\
\hline Between 31 and 40 years & $430(29.1)$ & $3.60(.64)$ & $3.42(.59)$ & $2.45(.75)$ & $3.86(.84)$ & $3.19(.90)$ & $2.49(.80)$ & $3.87(.77)$ \\
\hline Over 41 years & $84(5.7)$ & $3.69(.67)$ & $3.48(.60)$ & $2.48(.76)$ & $3.84(.86)$ & $3.32(.92)$ & $2.51(.80)$ & $3.78(.77)$ \\
\hline \multicolumn{9}{|l|}{ Professional situation } \\
\hline Distance learning only & $1227(83.0)$ & $3.58(.69)$ & $3.50(.61)^{\star \star}$ & $2.40(.76)$ & $3.87(.85)$ & $3.01(.91)$ & $2.54(.80)$ & $3.87(.79)$ \\
\hline Presential teaching only & $22(1.4)$ & $3.61(.74)$ & $3.55(.52)$ & $2.61(.81)$ & $3.90(1.07)$ & $2.98(1.06)$ & $2.39(.93)$ & $3.93(.93)$ \\
\hline The previous two & $230(15.6)$ & $3.62(.70)$ & $3.37(.65)$ & $2.42(.72)$ & $3.90(.82)$ & $2.97(.95)$ & $2.48(.72)$ & $3.92(.75)$ \\
\hline Total & $1479(100.0)$ & $3.59(.69)$ & $3.48(.62)$ & $2.41(.75)$ & $3.88(.85)$ & $3.00(.92)$ & $2.53(.79)$ & $3.88(.79)$ \\
\hline
\end{tabular}

$M$, mean; $S D$, standard deviation; ${ }^{\star \star \star} p<.01 ;{ }^{* *} p<.01 ;{ }^{*} p<.05$.

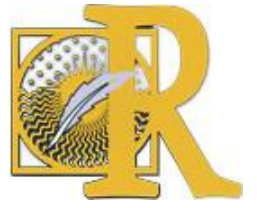


Regarding the aspect of professional well-being during the pandemic when compared to the previous period, it was found that the average score of positive perceptions $(M=2.41, S D=$ $0.75)$ is lower than the score of negative perceptions $(M=3.88, S D=0.85)$ and teaching difficulties $(M=3.00, S D=0.92)$. For this reason, according to the teachers surveyed, the COVID-19 pandemic decreased the perception of professional well-being and increased teaching difficulties.

Positive perceptions of professional well-being were more significant in teachers of pre-school education compared to teachers in the 1 st cycle of basic education $(Z(2.1433)=2,689, p$ $<.05$ ), while the negative perceptions and teaching difficulties were statistically different depending on the gender of the teachers $(t(1477)=-2,336, p<.05 ; t(1477)=-5,147, p<.001)$ and the level of education taught $(Z(4,1433)=4,460, p<.001 ; Z(4,1433)=5,626, p<.001)$. In other words, teachers had a higher score in the face of negative perceptions and teaching difficulties compared to teachers and teachers in pre-school education, a lower score compared to negative perceptions while teachers in the $1^{\text {st }}$ cycle of Basic Education and in the $3^{\text {rd }}$ Basic and Secondary Education cycle had the highest score in view of the perceptions of teaching difficulties. Still regarding professional well-being, it is important to report that the teachers who teach in the Algarve region were those who had a higher level of negative perceptions $(M=4.12, S D=0.83 ; Z(6,1465)=4.747, p<.001)$ and that the teachers with the longest service (over 41 years) had a score of perceived difficulties in teaching $(M=3.32, S D$ $=0.92 ; Z(4,1474)=11.599, p<.001)$.

Regarding future perspectives, it was noticed that the score of negative perceptions $(M=3.88$, $S D=0.79)$ is higher than that of positive perceptions $(M=2.53, S D=0.79)$. The bivariate analysis showed that teachers with less service time were those who reported more positive future perspectives.

The results of the models show that being female, having a service time of less than 20 years, increasing well-being, decreasing perceptions about teaching difficulties and increasing positive future perspectives, contribute to the increase in positive perceptions of professional well-being. Regardless, teaching in the Azores, having less than 10 years of service and the decrease in well-being diminish negative perceptions of professional well-being. The increase in perceptions associated with teaching difficulties and negative perspectives regarding the professional future increase the negative perceptions of professional well-being (Table 3). 
Table 3. Generalised Linear Model predicting professional wellbeing.

\begin{tabular}{|c|c|c|c|c|c|}
\hline \multirow[b]{3}{*}{ Independent variable } & & \multicolumn{2}{|c|}{$\begin{array}{l}\text { Dependent variable: } \\
\text { PSWBPSTP - Positive } \\
\text { Perceptions }\end{array}$} & \multirow{2}{*}{\multicolumn{2}{|c|}{$\begin{array}{l}\text { Dependent variable: } \\
\text { PSWBPSTP - Negative } \\
\text { Perceptions } \\
\text { Model } 2\end{array}$}} \\
\hline & & Model 1 & & & \\
\hline & & $\beta[95 \% \mathrm{Cl}]$ & $p$ value & $\beta[95 \% \mathrm{Cl}]$ & $p$ value \\
\hline \multicolumn{6}{|l|}{ Sex } \\
\hline Male & & $.915[.843-.994]$ & .035 & $.940\{.858-1.029]$ & .181 \\
\hline Female & & Ref. & & & 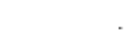 \\
\hline \multicolumn{6}{|l|}{ Region } \\
\hline North & & $1.025[.897-1.171]$ & .714 & $.936[.808-1.084]$ & .374 \\
\hline Center & & $.999[.872-1.144]$ & .987 & $1.010[.870-1.173]$ & .895 \\
\hline Lisbon and Tejo & & $1.007[.880-1.153]$ & .917 & $.873[.752-1.014]$ & .075 \\
\hline Alentejo & & $1.029[.838-1.262]$ & .787 & $.845[.674-1.059]$ & .143 \\
\hline Algarve & & $.920[.770-1.099]$ & .357 & $1.047[.861-1.274]$ & .644 \\
\hline Madeira & & $1.100[.925-1.308]$ & .281 & $.741[.613-.897]$ & .002 \\
\hline Azores & & Ref. & - & Ref. & - \\
\hline \multicolumn{6}{|l|}{ Level of education } \\
\hline Pre-school Education & & $1.092[.868-1.373]$ & .453 & $1.271[1.006-1.605]$ & .054 \\
\hline 1st cycle of Basic Education & & $.931[.783-1.107]$ & .420 & $1.103[.927-1.312]$ & .971 \\
\hline 2nd cycle of Basic Education & & $.983[.826-1.170]$ & .846 & $1.047[.891-1.232]$ & .212 \\
\hline $\begin{array}{l}\text { 3rd cycle of Basic Education and } \\
\text { Secondary Education }\end{array}$ & & $1.003[.856-1.177]$ & .966 & $.987[.837-1.164]$ & .567 \\
\hline Special Education & & Ref. & . & Ref. & . \\
\hline \multicolumn{6}{|l|}{ Length of service } \\
\hline Less than 10 years & & $.730[.591-.903]$ & .004 & $.780[.606-1.005]$ & .045 \\
\hline Between 11 and 20 years & & $.807[.689-.944]$ & .007 & $1.003[.829-1.215]$ & .270 \\
\hline Between 21 and 30 years & & $.864[.746-1.001]$ & .051 & $1.130[.933-1.370]$ & .575 \\
\hline Between 31 and 40 years & & $.966[.831-1.121]$ & .646 & $.950[.797-1.132]$ & .879 \\
\hline Over 41 years & & Ref. & - & Ref. & - \\
\hline \multicolumn{6}{|l|}{ Professional situation } \\
\hline Distance learning only & & $1.000[.910-1.099]$ & .997 & $.908[.819-1.008]$ & .070 \\
\hline Presential teaching only & & $1.197[.901-1.589]$ & .214 & $.997[.729-1.363]$ & .984 \\
\hline The previous two & & Ref. & . & Ref. & . \\
\hline WbHPS & & $1.132[.075-1.192]$ & .000 & $.807[.763-.854]$ & .000 \\
\hline SSES & & $1.033[.973-1.096]$ & .289 & $1.030[.965-1.100]$ & .375 \\
\hline $\begin{array}{l}\text { PSWbPSTP - Teaching Difficulties } \\
\text { Perceptions }\end{array}$ & & $.818[.788-.850]$ & .000 & $1.277[1.225-1.332]$ & .000 \\
\hline PFPS - Positive Perceptions & & $1.414[1.347-1.484]$ & .000 & $.959[.909-1.011]$ & .122 \\
\hline PFPS - Negative Perceptions & & $.957[.913-1.003]$ & .068 & $1.431[1.359-1.507]$ & .000 \\
\hline \multirow[t]{3}{*}{ Constant } & & $\begin{array}{r}6.580[4.178- \\
10.364]\end{array}$ & .000 & $\begin{array}{r}14.358[8.701- \\
23.691]\end{array}$ & .000 \\
\hline & $\mathrm{AIC}$ & & 2784.19 & & 3064.05 \\
\hline & $\mathrm{BIC}$ & & 2910.63 & & 3190.49 \\
\hline
\end{tabular}

\section{Discussion.}

In general, teachers were satisfied with the education system before the pandemic, with the exception of the Ministry of Education guidelines and the typical bureaucracy involved, previously taken into account by Portuguese teachers (Azevedo et al., 2016).

The results showed that most teachers have a moderately positive perception of well-being, as in the Portuguese study by Furtado and Medeiros (2017) and in other international studies

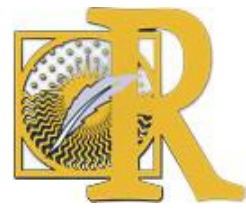

Fecha de recepción: 13-07-2020 Fecha de aceptación: 25-07-2020

Alves, R., Lopes, T \& Precioso, J. (2021). El bienestar de los docentes en tiempos de pandemia Covid-19: factores que explican el bienestar profesional 
(Konu et al., 2010; Kurt \& Demirbolat, 2019; Mehdinezhad, 2012). However, during the pandemic situation, teachers' well-being in relation to the profession decreased and the future professional perspectives considered by the interviewed teachers are not satisfactory.

In the scientific literature there are some inconsistencies regarding the relationship between the variable gender and professional well-being. Some studies do not identify any relationship between these variables (Demirel, 2014; Feng, 2007) and others report that, compared to male teachers, there were reports of higher levels of satisfaction among female ones (Huang \& Yin, 2018; Klassen \& Chiu, 2010). In the present study and as in others (Furtado \& Medeiros, 2017; Garrick et al., 2018; Sahito \& Vaisanen, 2020; Tang, 2018), the gender variable was a predictor of professional well-being, in a positive perspective, indicating that female teachers are more satisfied professionally than their male colleagues.

The length of service was considered to be a determinant of professional well-bei ng (Chan, 2006; Furtado \& Medeiros, 2017; Goroshit \& Hen, 2016; Huang \& Yin, 2018; Kotaman, 2016; Sahito \& Vaisanen, 2020; Tang, 2018), verifying that the level of positive perceptions regarding well-being decreases as the length of service increases. On the contrary, it was found that the more years of service teachers have, the greater their negative perceptions of the profession.

The systematic literature review carried out by Hongying (2007), maintained the existence of a U-shaped relationship between age and well-being or job satisfaction. This indicates that at the beginning of professional careers, teachers are highly satisfied and achieve an excellent level and sense of professional well-being, which tends to decrease over the years, but, on the contrary, to increase at the end of their careers (Tang, 2018; Zacher \& Schmitt, 2016), which is something that may be associated with the fact that teachers no longer expect anything new in view or possess any novel expectations or prospects of/for their profession (Furtado \& Medeiros, 2017).

In view of this aspect, it is important to think of strategies that support teachers with long careers (Virtanen et al., 2020), transforming the exercise of the profession into a healthy and free from burnout activity. International studies indicate that the professional well-being of teachers does not only affect them individually, but rather has profound implications for the education system itself as a whole (Huang \& Yin, 2018). This identifies the existence of an association between the well-being of teachers and the quality of teaching, with their commitment and professional effectiveness (Mclnerney et al., 2018) and with the emotional climate of the classroom (Becker et al., 2014).

Nonetheless, in the multivariate analysis, the level of education is not a predictor of professional well-being in times of pandemic. The bivariate analysis showed that teachers with lower education levels, especially teachers in Pre-school Education, reported higher levels of satisfaction and (professional) well-being, contrary to other studies (Huang \& Yin, 2018).

As in other studies (Briones et al., 2010; Çevik, 2017; Demirel, 2014; Kidger et al., 2016; Kurt \& Demirbolat, 2019), the well-being of teachers, namely their satisfaction with life, predicts professional well-being, since, on the one hand, the increase in WbHPS scores increases positive perceptions, and, on the other hand, the decrease in WbHPS scores increases negative perceptions regarding professional well-being.

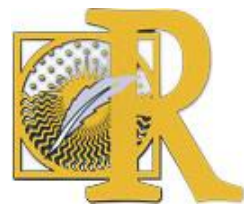

Fecha de recepción: 13-07-2020 Fecha de aceptación: 25-07-2020

Alves, R., Lopes, T \& Precioso, J. (2021). El bienestar de los docentes en tiempos de pandemia Covid-19: 
It is also important to argue that the well-being of teachers also affects the well-being of students (Harding et al., 2019; Katrin Arens \& Morin, 2016; Mclnerney et al., 2018), that is, when teachers feel good with work, students are more motivated (Moè et al., 2010), since their teachers are expected to play an important role in the behavioural and emotional modelling of said pupils (Sisask et al., 2014). Therefore, the reduced professional well-being recorded in this study may explain the results of the latest HBSC report, which indicates a low perception of well-being by Portuguese students (Inchley et al., 2020).

\subsection{Limitations and future directions.}

Some limitations must be considered in this study. First, we feel it necessary to mention that the collection of data in online format and through self-reported measures can cause some bias in the results ultimately presented. Secondly, the cross-sectional design of the study and through coexistence sampling does not allow one to hypothesize any type of causal relationship. Third, the data collection instruments used was specifically designed for the present study and although the psychometric analysis has shown good results, further studies on reliability and validity are needed. In the same sense and in fourth place, it should be noted that variables such as wages and self-efficacy were not included in the present study, although we are aware of their importance as predictors of professional well-being, since almost all studies conclude that low wages have a negative impact on teachers (Bullough et al., 2012) and refer to the perception of self-efficacy as the most significant factor in teachers' professional well-being (Yildirim, 2015).

The study of professional well-being in times of global pandemic provides a scientific basis for the development of interventions that have the power to improve the professional well-being of teachers, focusing on emotional management (Kidger et al., 2016; Puertas Molero et al., 2019; Pulido-Martos et al., 2016; Yin et al., 2013), through self-reflection strategies (Garrick et al., 2018) and cognitive self-regulation (Mattern \& Bauer, 2014), along with the development of digital skills (Yorulmaz et al., 2017), through collaborative work. Regarding teachers with long careers (Virtanen et al., 2020), it is important to think of strategies that support this class, highlighting the need for investment in public policies for reform (Furtado \& Medeiros, 2017) and, consequently, for the renewal of the teaching class.

\section{Conclusions.}

The present study showed that the pandemic has reduced the perception of well-being in the face of the profession, creating some concern among teachers about their professional future. Being male, having a lengthier time of service, more difficulties in teaching and a more negative perception of the professional future contribute to the decrease in the overall professional well-being of teachers.

This study emphasizes the importance of creating conditions for the retirement of teachers with long careers and with signs of professional distress to allow the constant renewal of the teaching class, with the satisfaction of teachers affecting the well-being and motivation of students as a direct consequence, factors that assume great importance in the academic success of students.

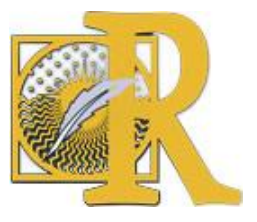

Fecha de recepción: 13-07-2020 Fecha de aceptación: 25-07-2020 
This research exercise makes it clear that keeping an ongoing exploration of the prevalence of (professional) well-being in the career of teachers is vital, and a fundamental aspect in order to update the information in this research field, exploring the tendencies, nuances and changes, especially in times of crisis, such as the current one, caused by the COVID-19 pandemic. Moreover, studies carried out in this field have the power to call people to action in the school context, having an impact, on one hand, on the teaching methods and, on the other hand, on the professional performance displayed by the teachers. These aspects highlight to an ever greater extent, and once again, the importance of researching the well-being in certain specific circumstances, as the ones presented by COVID-19, its consequences and its ultimate results, in order to provide governments with better tools and equip them with more and better information so as to enable them to elaborate and apply and implement the necessary educational policies and reforms.

It is our hope that our research may have contributed for a better understanding of the professional well-being of teachers in the context of the current, ongoing pandemic, and that it has brought forth and made available new, essential knowledge in this research area.

\section{References.}

- Alves, R. F., Precioso, J. A. G., \& Becona, E. (2020). Well-being and health perception of university students in Portugal: the influence of parental support and love relationship. Health Psychology Report, 8(2), 145-154. https://doi.org/10.5114/hpr.2020.94723

- Azevedo, J., Veiga, J., \& Ribeiro, D. (2016). As preocupações e motivações dos professores: apresentação dos resultados de um inquérito (Fundação M). Vila Nova de Gaia, Portugal.

- Aziri, B. (2011). Job satisfaction: a literature review. Management Research and Practice, 3(4), 77-86.

- Becker, E. S., Goetz, T., Morger, V., \& Ranellucci, J. (2014). The importance of teachers' emotions and instructional behavior for their students' emotions - An experience sampling analysis. Teaching and Teacher Education, 43, 15-26. https://doi.org/10.1016/j.tate.2014.05.002

- Briones, P. E., Urbieta, T. C., \& Arenas, M. A. (2010). Job Satisfaction of Secondary School Teachers: Effect of Demographic and Psycho-Social Factors. Revista de Psicología Del Trabajo y de Las Organizaciones, 26(2), 115-122. https://doi.org/10.5093/tr2010v26n2a3

- Bullough, R. V., Hall-Kenyon, K. M., \& MacKay, K. L. (2012). Head Start Teacher WellBeing: Implications for Policy and Practice. Early Childhood Education Journal, 40(6), 323331. https://doi.org/10.1007/s10643-012-0535-8

- Çevik, G. B. (2017). The Roles of Life Satisfaction, Teaching Efficacy, and Self-esteem in Predicting Teachers' Job Satisfaction. Universal Journal of Educational Research, 5(3), 338-346. https://doi.org/10.13189/ujer.2017.050306

- Chan, D. W. (2006). Emotional intelligence and components of burnout among Chinese secondary school teachers in Hong Kong. Teaching and Teacher Education, 22(8), 10421054. https://doi.org/10.1016/j.tate.2006.04.005

- Christensen, L. B., Johnson, B., \& Turner, L. A. (2015). Research methods, design, and

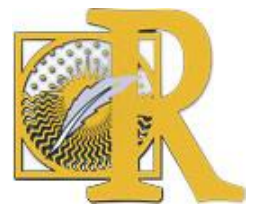

Fecha de recepción: 13-07-2020 Fecha de aceptación: 25-07-2020 Alves, R., Lopes, T \& Precioso, J. (2021). El bienestar de los docentes en tiempos de pandemia Covid-19: factores que explican el bienestar profesional 
analysis. Boston: Pearson.

- Collie, R. J., Shapka, J. D., Perry, N. E., \& Martin, A. J. (2015). Teacher Well-Being: Exploring Its Components and a Practice-Oriented Scale. Journal of Psychoeducational Assessment, 33(8), 744-756. https://doi.org/10.1177/0734282915587990

- Demirel, H. (2014). An investigation of the relationship between job and life satisfaction among teachers Selection and peer review under the responsibility of Prof. Dr. Servet Bayram. Procedia-Social and Behavioral Sciences, 116, 4925-4931. https://doi.org/10.1016/j.sbspro.2014.01.1051

- Diener, E., Lucas, R. E., \& Oishi, S. (2018). Advances and Open Questions in the Science of Subjective Well-Being. Collabra: Psychology, 4(1), 15. https://doi.org/10.1525/collabra.115

- Feng, B. (2007). A study of teacher job satisfaction and factors that influence it. Chinese Education and Society, 40(5), 47-64. https://doi.org/10.2753/CED1061-1932400506

- Furtado, S. C. O., \& Medeiros, T. (2017). Subjective well-being of teachers in preretirement. Revista de Estudios e Investigación En Psicología y Educación, 4(2), 99. https://doi.org/10.17979/reipe.2017.4.2.1889

- Garrick, A., Mak, A. S., Cathcart, S., Winwood, P. C., Bakker, A. B., \& Lushington, K. (2018). Non-Work Time Activities Predicting Teachers' Work-Related Fatigue and Engagement: An Effort-Recovery Approach. Australian Psychologist, 53(3), 243-252. https://doi.org/10.1111/ap.12290

- Goroshit, M., \& Hen, M. (2016). Teachers' empathy: can it be predicted by self-efficacy? Teachers and Teaching: Theory and Practice, 22(7), 805-818. https://doi.org/10.1080/13540602.2016.1185818

- Gursel, M., Sunbul, A. M., \& Sari, H. (2002). An analysis of burnout and job satisfaction between Turkish headteachers and teachers. European Journal of Psychology of Education, 17(1), 35-45. Retrieved from http://www.jstor.com/stable/23421427

- Harding, S., Morris, R., Gunnell, D., Ford, T., Hollingworth, W., Tilling, K., ... Kidger, J. (2019). Is teachers' mental health and wellbeing associated with students' mental health and wellbeing? Journal of Affective Disorders, 242, 180-187. https://doi.org/10.1016/j.jad.2018.08.080

- Hongying, S. (2007). Literature Review of Teacher Job Satisfaction. Chinese Education \& Society, 40(5), 11-16. https://doi.org/10.2753/CED1061-1932400502

- Huang, S., \& Yin, H. (2018). Teacher Efficacy and Affective Well-Being in Hong Kong: An Examination of Their Relationships and Individual Differences. ECNU Review of Education, 1(2), 102-126. https://doi.org/10.30926/ecnuroe2018010205

- Inandi, Y., Tunç, B., \& Uslu, F. (2013). Relationship between job satisfaction and career barriers for the academic staff of the education faculties. Journal of Educational Sciences Research, 3(1), 219-238. https://doi.org/10.12973/jesr.2013.3112a

- Inchley, J. C., Currie, D., Budisavljevic, S., Torsheim, T., Jåstad, A., Cosma, A., ... Arnarsson, Á. M. (2020). Spotlight on adolescent health and well-being. Findings from the 2017/2018 Health Behaviour in School-aged Children (HBSC) survey in Europe and Canada. International report. Volume 1. Key findings. (Vol. 1). Copenhagen. Retrieved from

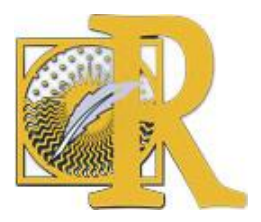


www.euro.who.int

- Jensen, B., Sandoval-Hernández, A., Knoll, S., \& Gonzalez, E. J. (2012). The Experience of New Teachers: Results from TALIS 2008 (TALIS). OECD. https://doi.org/10.1787/9789264120952-en

- Katrin Arens, A., \& Morin, A. J. S. (2016). Relations between teachers' emotional exhaustion and students' educational outcomes. Journal of Educational Psychology, 108(6), 800-813. https://doi.org/10.1037/edu0000105

- Kidger, J., Brockman, R., Tilling, K., Campbell, R., Ford, T., Araya, R., ... Gunnell, D. (2016). Teachers' wellbeing and depressive symptoms, and associated risk factors: A large cross sectional study in English secondary schools. Journal of Affective Disorders, 192, 76-82. https://doi.org/10.1016/j.jad.2015.11.054

- Klassen, R. M., \& Chiu, M. M. (2010). Effects on Teachers' Self-Efficacy and Job Satisfaction: Teacher Gender, Years of Experience, and Job Stress. Journal of Educational Psychology, 102(3), 741-756. https://doi.org/10.1037/a0019237

- Konu, A., Viitanen, E., \& Lintonen, T. (2010). Teachers' wellbeing and perceptions of leadership practices. International Journal of Workplace Health Management, 3(1), 44-57. https://doi.org/10.1108/17538351011031939

- Kotaman, H. (2016). Turkish early childhood teachers' emotional problems in early years of their professional lives. European Early Childhood Education Research Journal, 24(3), 365-381. https://doi.org/10.1080/1350293X.2014.970849

- Kurt, N., \& Demirbolat, A. O. (2019). Investigation of the Relationship Between Psychological Capital Perception, Psychological Well-Being and Job Satisfaction of Teachers. Journal of Education and Learning, 8(1). https://doi.org/10.5539/jel.v8n1p87

- Kyriacou, C. (2001). Teacher stress: Directions for future research. Educational Review, 53(1), 27-35. https://doi.org/10.1080/00131910120033628

- Mattern, J., \& Bauer, J. (2014). Does teachers' cognitive self-regulation increase their occupational well-being? The structure and role of self-regulation in the teaching context. Teaching and Teacher Education, 43, 58-68. https://doi.org/10.1016/j.tate.2014.05.004

- Mclnerney, D. M., Korpershoek, H., Wang, H., \& Morin, A. J. S. (2018). Teachers' occupational attributes and their psychological wellbeing, job satisfaction, occupational self-concept and quitting intentions. Teaching and Teacher Education, 71, 145-158. https://doi.org/10.1016/j.tate.2017.12.020

- Mehdinezhad, V. (2012). Relationship between High School teachers' wellbeing and teachers' Acta Scientiarum. Education, 34(2). https://doi.org/10.4025/actascieduc.v34i2.16716

- Moè, A., Pazzaglia, F., \& Ronconi, L. (2010). When being able is not enough. The combined value of positive affect and self-efficacy for job satisfaction in teaching. Teaching and Teacher Education, 26(5), 1145-1153. https://doi.org/10.1016/j.tate.2010.02.010

- Puertas Molero, P., Zurita Ortega, F., Ubago Jiménez, J. L., \& González Valero, G. (2019). Influence of Emotional Intelligence and Burnout Syndrome on Teachers Well-Being: A Systematic Review. Social Sciences, 8(6), 185. https://doi.org/10.3390/socsci8060185

- Pulido-Martos, M., Lopez-Zafra, E., Estévez-López, F., \& Augusto-Landa, J. M. (2016). The

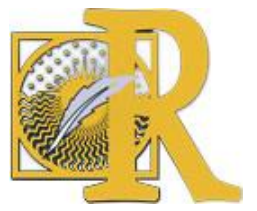


Moderator Role of Perceived Emotional Intelligence in the Relationship between Sources of Stress and Mental Health in Teachers. Spanish Journal of Psychology, 19. https://doi.org/10.1017/sjp.2016.8

- Reimer, F. M., \& Schleicher, A. (2020). Schooling Disrupted, Schooling Rethought: How the Covid-19 pandemic is changing education.

- Sahito, Z., \& Vaisanen, P. (2020). A literature review on teachers' job satisfaction in developing countries: Recommendations and solutions for the enhancement of the job. Review of Education, 8(1), 3-34. https://doi.org/10.1002/rev3.3159

- Sisask, M., Värnik, P., Värnik, A., Apter, A., Balazs, J., Balint, M., ... Wasserman, D. (2014). Teacher satisfaction with school and psychological well-being affects their readiness to help children with mental health problems. Health Education Journal, 73(4), 382-393. https://doi.org/10.1177/0017896913485742

- Skaalvik, E. M., \& Skaalvik, S. (2015). Job satisfaction, stress and coping strategies in the teaching profession-what do teachers say? International Education Studies, 8(3), 181-192. https://doi.org/10.5539/ies.v8n3p181

- Spector, P. (1997). Job Satisfaction: Application, Assessment, Causes, and Consequences. 2455 Teller Road, Thousand Oaks California 91320 United States: SAGE Publications, Inc. https://doi.org/10.4135/9781452231549

- Spilt, J. L., Koomen, H. M. Y., \& Thijs, J. T. (2011, December 12). Teacher Wellbeing: The Importance of Teacher-Student Relationships. Educational Psychology Review. Springer. https://doi.org/10.1007/s10648-011-9170-y

- Tang, Y. (2018). What makes rural teachers happy? An investigation on the subjective wellbeing (SWB) of Chinese rural teachers. International Journal of Educational Development, 62, 192-200. https://doi.org/10.1016/j.ijedudev.2018.05.001

- Virtanen, A., De Bloom, J., \& Kinnunen, U. (2020). Relationships between recovery experiences and well-being among younger and older teachers. International Archives of Occupational and Environmental Health, 93(2), 213-227. https://doi.org/10.1007/s00420019-01475-8

- Yildirim, K. (2015). Testing the main determinants of teachers' professional well-being by using a mixed method. Teacher Development, 19(1), 59-78. https://doi.org/10.1080/13664530.2014.970663

- Yin, H. biao, Lee, J. C. K., Zhang, Z. hua, \& Jin, Y. le. (2013). Exploring the relationship among teachers' emotional intelligence, emotional labor strategies and teaching satisfaction. Teaching and Teacher Education, 35, 137-145. https://doi.org/10.1016/j.tate.2013.06.006

- Yorulmaz, Y. I., Colak, I., \& Altinkurt, Y. (2017). A Meta-Analysis of the Relationship Between Teachers' Job Satisfaction and Burnout. Eurasian Journal of Educational Research, 17(71), 175-192. https://doi.org/10.14689/ejer.2017.71.10

- Zacher, H., \& Schmitt, A. (2016). Work Characteristics and Occupational Well-Being: The Role of Age. Frontiers in Psychology, 7. https://doi.org/10.3389/fpsyg.2016.01411

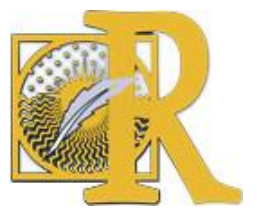

Fecha de recepción: 13-07-2020 Fecha de aceptación: 25-07-2020 Alves, R., Lopes, T \& Precioso, J. (2021). El bienestar de los docentes en tiempos de pandemia Covid-19: factores que explican el bienestar profesional 